\title{
Sex with Animals in Early Modern Russia: Legal Spaces of Negotiating the Boundaries of Humanity
}

\author{
Marianna Muravyeva \\ University of Helsinki \\ marianna.muravyeva@helsinki.fi
}

\begin{abstract}
:
Sex with animals constitutes a problematic field of study in the history of sexuality. Based on 101 cases of prosecution for engaging in sex with animals in early modern Russia, the article examines legal and cultural approaches to cross-species sexual relations that became visible in the course of prosecution for sex with animals. The analysis reveals that sex with animals was stigmatized as an impermissible sexual practice degrading for humanity, which was put in the form of "pakost"' (filth) and "skvernost" (foulness), and as a form of animal abuse that revealed proto-modern approaches to the notions of consent and abuse as crucial for constructing the new "man". The discussion is contextualized in broader literature on sex with animals to highlight how European and colonial societies dealt with common concerns about sex with animals in the seventeenth and eighteenth centuries and if, how and why Russian way differed from other contexts. Russian evidence points to the anxieties over observing strict boundaries between species, that might result in crossbreeding. Russian courts approached sex with animals as a type of abuse of one's body and the body of an animal focusing on ways to justify the lack of consent by blaming it on alcohol or other impairments of the faculties. It reinforced the idea that cross-species copulation was not a choice but rather the absence of it.
\end{abstract}

Keywords:

sex with animals, early modern Russia, history of sexuality, history of animal abuse

On April 26, 1730, Moscow police arrested a monk, Iona, from a monastery in Nizhnii Novgorod, who handed them a locked box that contained a sealed notebook (tetradka) about miracles and a written petition (proshenie) for the newly-enthroned Empress Anna Ioannovna. The notebook contained a detailed description of miracles he had witnessed in 1729-1730 and an important message he had learnt from angels' voices (angel'skie golosa): they told him to pass on to the empress their request to prohibit swearing, fornication, dancing and all entertainment during Lent and other holidays. The police quickly handed Iona over to the Holy Synod for assessment. The monk ended up together with dozens of other "walkers" (khodoki) and runaways who regularly descended upon Moscow. Iona's case would never have stood out if not for the peculiar nature of his notes and confessions. His petition did not just include the types of behavior that he believed should be prohibited, but also the requisite punishment: as a deterrent for swearing he proposed that the offender's tongue should be cut; as a deterrent against fornication he advocated that a fornicator's penis (tainyi ud) should be cut and so on. Iona argued for these proposals by drawing on his own example: he shared that when his wife had died in 1720 he "fornicated with his cow" (palsia so skotom svoim bludno. He subsequently repented for committing this sin until he found a way to prevent such an occurrence in the future by castrating himself in 1729. A medical exam was arranged immediately by the Holy Synod. The surgeon found that Iona was indeed castrated, but not surgically; his penis had been crudely hacked with a sharp instrument-a kitchen knife-as Iona confirmed. 
Iona's confession of having engaging in sex with a cow (skotolozhstvo) and his subsequent self-castration persuaded the members of the Holy Synod that the monk was mentally challenged (na golovu plokh). They looked into the account of his wanderings, which formed part of their interrogation of the monk. Iona stated several times that he decided to take monastic views in 1729 when he became ill. During his peregrinations between January and April 1730 he mentioned "being ill" at least four times. This probably saved him from the charge of blasphemy and other religious offences, which might have resulted in the death penalty in 1730. After the investigation was concluded, Iona was charged with leaving his monastery without permission (pobeg), intricate and inverted miracles (vymyshlennye i zateinye chudesa), fantastic nonsense (svoemudrstvennye bredni), utter insolence and the filthy crime of sex with an animal (pakost'skotolozhstva). For these Iona was sentenced to penal labor for life at mines in Siberia. ${ }^{1}$

Iona was one of many men who committed "filth," but he was the only one who confessed his "sin;" others were mostly caught in the act or were reported by witnesses. Iona felt he had degraded himself and lost his human status; to compensate for this loss he sacrificed his masculinity. Being a priest and a deeply religious person, he probably conceptualized his actions as getting rid of the sinful flesh in order to save his soul. The court narrative suggests that this experience was crucial in motivating Iona to leave the monastery and to travel to Moscow in order to seek an audience with the empress. His visions and the instructions he purportedly received from angels attest to his deep reflection on human sexuality and the boundaries of the permissible application of sexual drive. However, the Synod did not want to undertake further investigations and it was satisfied with his explanation of skotolozhstvo. Thus, they perceived his behavior as filth (pakost'), which indicates that the official attitude to interspecies copulation was dismissive and low-key. The authorities were much more concerned with the fact that Iona had run away and petitioned the empress with "fantastic nonsense," rather than in his sexual intercourse with a cow. They excused this latter behavior by referring to his disturbed mental health.

Iona's case brings to light a set of problematic questions that have rarely been addressed by scholars. Iona was one of approximately a hundred men who ended up prosecuted for sex with animals in the seventeenth and eighteenth centuries. I have discovered 101 more or less complete cases so far after a systematic search in the criminal records of agencies responsible for criminal prosecution between 1600 and 1800 . There are about the same amount of mentions of sex with animals in court records, but they cannot be located for a variety of reasons. ${ }^{2}$ The cases under consideration in this article do not represent the

\footnotetext{
${ }^{1}$ Rossiiskii gosudarstvennyi istoricheskii arkhiv (hereafter RGIA). f. 796, op. 11, d. 175.

${ }^{2}$ I have been working on the database for about 10 years. It includes case law extracted from surviving court records found in Russian central and regional archives. The database contains 12,000 entries for crimes within the family and sex crimes. Central administrative bodies include the Military Chancellery (Razriadnyi prikaz) for the seventeenth century (RGADA coll. 210) and the Military Collegium for the eighteenth century (RGVIA coll. 8), the Senate - the high appeal court and administrative body in the eighteenth century (RGADA coll. 248; RGIA coll. 1345, 1346), the Collegium of Justice (RGADA coll. 285), the Holy Synod - the high appeal court and administrative body for ecclesiastical affairs in the eighteenth century (RGIA coll. 796, 797) and Moscow Synodal Office (RGADA coll. 1183). The regional bodies include regional chancelleries and courts (TsGIA SPB coll. 19, 1709, 1716, 1724, 1727, 1734, 1740, 1744, 1748; RGADA coll. 372, 373, 400-1181; RNB coll. 299; TsANO coll. 570; GAPO coll. 39, 55, 6o, 105; GAT coll. 156, 360) and others. On the crime database see, Marianna Muravyeva, "Family Authority, Violence against Parents, and Parricide in Russia, 1600-180o," Journal of Family History 41 no. 3 (2016): 294-317. On the criminal justice system in the seventeenth and eighteenth centuries, see Nancy Kollmann, Crime and Punishment in Early Modern Russia (Cambridge: Cambridge University Press, 2012); Marianna Muravyeva, "Russian Law in the Early Modern Period," Oxford
} 
assessment of the prevalence of sex with animals. What they do present is the priorities of the authorities and communities regarding what kind of sex practices they chose to prosecute, that is, how dangerous they thought sex with animals was to their wellbeing. These cases provide evidence of how authorities and communities explained the motivations for sex with animals; who the offenders were; what kind of sexual practices were considered abusive; and how people viewed the consequences of sex with animals.

In this article, I will address these issues with the intent of examining legal and cultural approaches to cross-species sexual relations that became visible in the course of prosecutions against those accused of having sex with animals. I will, first, contextualize the discussion in broader literature on sex with animals in order to highlight how European and colonial societies dealt with common concerns about what was deemed to be deviant behavior in the past and if, how and why Russian customs differed from other contexts. I will then show that sex with animals was stigmatized in Russia as an impermissible sexual practice that was degrading for humanity. I will also highlight how authorities interpreted such acts in terms of "pakost" (filth) and "skvernost" (foulness) by analyzing legal and moral discourses on the topic. Furthermore, I will analyze how the Russian authorities judged abuse of one's body and the bodies of animals by analyzing the narratives of the cases. This will enable me to focus on the ways the Russian authorities sought to justify the lack of consent by blaming it on the impairment of the faculties of those who were accused of bestiality.

\section{Animal Abuse or Sexual Orientation: (De)Historicizing Sex with Animals}

Human and animal sexualities represent a problematic field of study, especially when the issue of cross-species copulation comes under scrutiny. In modern Western cultures and their colonized affiliates, some ambiguity persists as to how sex with animals should be viewed: whether or not it should be tolerated, punished as a form of animal abuse, or perceived as a sign of mental disturbance, or treated as a sexual orientation. Russian prerevolutionary, Soviet and post-Soviet academic, mostly criminological, literature includes all three trends and has followed European debates on this topic. ${ }^{3}$

In the early 2000s, Piers Beirne posed a question: "how should we approach bestiality: is it an outrageous and perhaps perverse act, or, as the law's increasing tolerance of it suggests, a relatively benign form of social deviance? Why have sexual relations involving humans and animals been so vociferously and ubiquitously condemned and so little studied?" ${ }^{4}$ Narratives of sex with animals, indeed any discussion of the topic, have a disturbing and uncomfortable ring to modern ears. Yet such contact, as Joyce Salisbury pointed out in 1994, has almost surely always occurred for as long as people have lived in

European Legal History Handbook, ed. by Heikki Pihlajamaki, Markus D. Drubber and Mark Godfrey (Oxford: Oxford University Press, 2018), 854-875.

${ }^{3}$ On the pre-revolutionary criminological approaches to sex with animals, see Marianna Muravyeva, "Legal Definitions of Sex Crimes in the Laws and Commentaries of Russian Lawyers (186os-1910s)," Women's History in Russia: (Re)Establishing the Field, ed. Marianna Muravyeva and Natalia Novikova (Cambridge: Cambridge Scholars Publishing, 2014), 28-49. See also, for example, Ivan Godnev, O passivnom skitolozhstve (Kazan': Universitetskaia tip., 1881); Nikolai Puzanov, O prestuplenii skotolozhstva po ulozheniiu o nakazaniiakh (Moscow: Universitetskaia tip., 1876); N. N. Konovalov, Seksual'nye prestupleniia: istoricheskii, antropologicheskii i etnograficheskii aspekty (Moscow: Rusains, 2017); Vsevolod Loba, "K voprosu ob otvetstvennosti zhivotnykh i neodushevlennykh predmetov: fragmenty istorii," Zakon i zhizn 1 (2017): 14-32. ${ }^{4}$ Piers Beirne, "On the Sexual Assault of Animals: A Sociological View," in The Animal/Human Boundary: Historical Perspectives, ed. by Angela N. H. Creager and William Chester Jordan (Rochester, NY: University of Rochester Press, 2002), 195. 
close contact with animals. ${ }^{5}$ While modern scholars readily examine the history of other areas of sexuality, sex with animals remains largely outside the political agendas and ethical debates that occupy many scholars. As such, it has remained in the background as a part of the seedy underbelly of early modern and modern culture. ${ }^{6}$

A potential reason for this silence relates to the nature of the practice and how it has been viewed by European and colonized societies since the early medieval period. Sex with animals was perceived so negatively that its very name was censured. From the sixteenth and seventeenth centuries, at least in Europe, it was spoken about only as "that unmentionable vice," "a sin too fearful to be named," or "among Christians a crime not to be named." It was feared that spreading information about this crime would lead to a spread in its practice. ${ }^{8}$ However, this negative view was not always widely shared. Joyce Salisbury, Hani Miletski and Andrea M. Beetz have all argued that sexual intercourse with animals may have been an expression of human sexuality for as long as animals have been domesticated. ${ }^{9}$

The majority of research on the history of sex with animals that has been carried out to date relates to the early modern and modern periods. Much of this scholarship has originated in English-speaking contexts, including colonies. ${ }^{10}$ Research on non-English speaking areas includes Finland, Sweden, The Netherlands, Spain and Latin America. ${ }^{11}$

\footnotetext{
${ }^{5}$ Joyce Salisbury, The Beast Within: Animals in the Middle Ages (New York: Routledge, 1994), 84.

${ }^{6}$ Courtney Thomas, “Not Having God Before his Eyes': Bestiality in Early Modern England,” The Seventeenth Century 26:1 (2011): 149-173.

${ }^{7}$ Beirne, "On the Sexual Assault," 197; Erica Fudge, "Monstrous Acts: Bestiality in Early Modern England," History Today 50: 8 (2000): 20-25, at 21; Erica Fudge, Perceiving Animals: Humans and Beasts in Early Modern English Culture (Urbana: University of Illinois Press, 2002), 137-38.

8 Jens Rydström, Sinners and Citizens: Bestiality and Homosexuality in Sweden, 1880-1950 (Chicago: University of Chicago Press, 2003), 64.

${ }^{9}$ Salisbury, The Beast Within, 84; Hani Miletski, "A History of Bestiality," in Bestiality and Zoophilia: Sexual Relations with Animals, ed. A. Beetz and A. Podberscek (West Lafayette, IN: Purdue University Press, 2005), 1-22; Andrea M. Beetz, "Bestiality, Zoophilia: A Scarcely Investigated Phenomenon between Crime, Paraphilia and Love," Journal of Forensic Psychology Practice 4, no. 2 (2004): 1-36, at 2, 4.

${ }^{10}$ Carl J. Griffin, "Animal Maiming, Intimacy and the Politics of Shared Life: The Bestial and the Beastly in Eighteenth- and Early Nineteenth-Century England," Transactions of the Institute of British Geographers 37, no. 2 (2012): 301-16. See also, Erica Fudge, Perceiving Animals: Humans and Beasts in Early Modern English Culture (Urbana: University of Illinois Press, 2002); Fudge, "Monstrous Acts: Bestiality in Early Modern England"; A. D. Harvey, "Bestiality in Late-Victorian England," Journal of Legal History 21, no. 3 (2000): 8588; Thomas, “Not Having God Before his Eyes': Bestiality in Early Modern England;" Andrew Wells, "Blurred Lines: Bestiality and the Human Ape in Enlightenment Scotland," in Interspecies Interactions: Animals and Humans between the Middle Ages and Modernity, ed. by Sarah Cockram and Andrew Wells (London: Routledge, 2017), 141-166; John M. Murrin, “Things Fearful to Name’: Bestiality in Early America,” in The Animal Human Boundary: Historical Perspectives, ed. Angela N. H. Creager and William Chester Jordan (Rochester, NY: University of Rochester Press, 2002); John Canup, “The Cry of Sodom Enquired Into': Bestiality and the Wilderness of Human Nature in Seventeenth Century New England," American Antiquarian Society 98 (1988): 113-34; Doron S. Ben-Atar and Richard D. Brown, Taming Lust: Crimes Against Nature in the Early Republic (Philadelphia: University of Pennsylvania Press, 2014); Sarah Carr, "Public Silence and Police Surveillance: Conflicting Attitudes to Bestiality in Colonial Otago," Journal of the History of Sexuality 25, no. 3 (2016): 420-436; Anne-Marie Collins, "Woman or Beast? Bestiality in Queensland, 18701949," Hecate 17, no. 1 (1991): 36-42.

" Teemu Keskisarja, “Secoituxesta järjettömäin luondocappalden canssa’: Perversiot, oikeuselämä ja kansankulttuuri 1700-luvun Suomessa" (University of Helsinki, 2006); Jonas Liliequist, "Peasants Against Nature: Crossing the Boundaries Between Man and Animal in Seventeenth and Eighteenth Century Sweden," Journal of the History of Sexuality 1, no. 3 (1991): 393-423; Rydström, Sinners and Citizens; Midas Dekker, Dearest Pet: On Bestiality (New York: Verso, 1994); Peter Boomgaard, "Male-Male Sex, Bestiality and Incest in the Early-Modern Indonesian Archipelago: Perceptions and Penalties," in Sexual Diversity in Asia, c. 6oo-
} 
Russia seems to be glaringly absent from this research, mostly due to underdeveloped histories of sexualities. Those that exist focus on either descriptions of laws or folklore and culture. ${ }^{12}$ Rare publications on the history of sex crimes include mentions of sex with animals, mostly following the rhetoric of cases they look at uncritically or for entertainment purposes. $^{13}$

Scholarly research highlights some problematic issues with using legal categories used by ecclesiastical and secular writings at various historical periods and in specific historical and cultural contexts that may be deemed to be misleading today. One such category is "bestiality." The English term "bestiality" entered into an English legal context in 1611 with the publication of the King James Bible and covered all sexual relations with beasts in a wider sense, although it suggested animals in the first place. ${ }^{14}$ Bestiality could mean possession of the qualities of a beast as well as an "unnatural" connection to a beast. The other term used is buggery (as similar to sodomy), which was originally stipulated in Henry VIII's Buggery Acts. ${ }^{15}$ This term is not sufficient within the context of Russian usage. The Russian legal term skotolozhstvo, which is used both in ecclesiastical and secular documents does not include any connotation of magical involvement or possession of animal qualities; it is a legal term (although again, not close to buggery) specifying sex with animals in a general sense (not how a sexual act was committed).

The problem is not the notion per se, but the connotation of perverse desire it invokes that rules out other interpretations (such as animal abuse) and gives space to psychopathological discourses in explaining the practice. The notion of "bestiality," which was predominantly used by historians of sexuality in the 1990 and early 200os, invokes certain approaches to sex with animals as a perverse and depraved practice, concentrating on sex and sexual transgression. The definition debate corresponds with contemporary scholarship's division into two camps: those scholars who follow the psychopathological framework looking at sex with animals as a paraphilia (sexual perversion) and scholars who treat sex with animals as animal abuse. ${ }^{16}$ Thus, Russian literature is highly invested in approaches to motivations for sex with animals, as a psychopathological condition, a paraphilia, that needs psychiatric treatment, otherwise it serves as an additional motivational characteristic for rape and serial sex abuse. ${ }^{17}$ Paraphilia as a category also

1950, ed. Raquel Reyes and William Gervase Clarence-Smith (London-New York: Routledge, 2012), 157-176; André Fernández, "The Repression of Sexual Behavior by the Aragonese Inquisition between 1560 and 1700," Journal of the History of Sexuality 7, no. 4 (1997): 469-501; Milada Bazant, "Bestiality: The Nefarious Crime in Mexico, 1800-1856," in Sexuality and the Unnatural in Colonial Latin America, ed. Zeb Tortorici (Berkeley: University of California Press, 2016), 130-145; Zeb Tortorici, Sins Against Nature: Sex and Archives in Colonial New Spain (Durham, NC: Duke University Press, 2018).

${ }^{12}$ Konovalov, Seksual'nye prestupleniia; Eduard Georgievskiy, Religioznye osnovaniia ugolovno-pravovykh zapretov: ot arkhaicheskogo politeizma $k$ russkomu pravoslaviiu (Moscow: Iurlitinform, 2014).

${ }^{13}$ See, for example, Vladimir Bezgin, "Protivoestestvennye poroki v kesti'ianskoi srede (vtoraia polovina XIX - nachalo XX veka)," Genesis: istoricheskie issledovaniia 2 (2016): 108-120.

${ }^{14}$ The English word "bestiality" derived from the old French bestialite, which was itself from the Latin bestia. For the etymology of the word, see "Bestiality," Oxford Learner's Dictionary, Oxford University Press, December 15, 2019, https://oxfordlearnersdictionaries.com/us/definition/english/bestiality.

${ }^{15}$ On usage in the English language, see "Bestiality," Oxford English Dictionary Online, Oxford University Press, December 15, 2019. https://www.oed.com/view/Entry/18199? redirectedFrom=bestiality\#eid. See also, Piers Beirne, Confronting Animal Abuse: Law, Criminology, and Human-animal Relationships (Lanham, MD: Rowman \& Littlefield, 2009), 105-106; Fudge, "Monstrous Acts"; Thomas, "Not Having God Before his Eyes". ${ }^{16}$ Piers Beirne, "Rethinking bestiality: Towards a concept of interspecies sexual assault," Theoretical Criminology 1, no. 3 (1997): 317-340; Piers Beirne, "On the Sexual Assault of Animals: A Sociological View," in Creager and Jordan, The Animal Human Boundary, 193-227.

${ }^{17}$ A. A. Tkachenko, Seksual'nye izvrashcheniia-parafilii (Moscow: Triada-X, 1999); A. A. Tkachenko, G. E. Vvedenskii, N. V. Dvorianchikov, Sudebnaia Seksologiia (Moscow: Meditsina, 2001); Vladimir Mendilevich, 
includes another term-zoophilia-that is highly problematic and eroticized, but used by historians in a false attempt to show tolerant attitudes. ${ }^{18}$

In this article, I would like to depart from such biased terminology and use the neutral "sex with animals" (unless I cite the documents and/or other researchers) to cover any interspecies sexual contact to allow for the possibility to examine my sources without predated concepts, even if they were generated in the timeframe I am looking at. Following this methodological statement, the article explores the boundaries of human sexuality within certain legal and cultural frameworks in order to see how early modern Russian society negotiated permissible behavior, consent and human/animal dignity. The Russian case is investigated within a comparative framework of early modern European and colonial evidence of sex with animals to provide a perspective on human-animal relationships during the period of finalizing Christian anthropogenesis discourses.

\section{"Blud s chetveronogi skoty" (Fornication with Four-Legged Animals): ${ }^{19}$ Perpetrators, Motives and Narratives of Sex with Animals}

Scholars have amassed more or less reliable data on prosecutions for sex with animals for the period between 1600 and 1800 . The cases appear to suggest a surprising continuity of attitudes toward sex between humans and animals, hinting at some international consensus. Studies have identified a common set of features in such prosecutions. First, criminal prosecutions have been very rare events, with the notable exception of the Swedish Empire and Aragon. Second, judges often appear to have been reluctant to apply maximum penalties when prosecutions were successful, except in the Swedish Empire. ${ }^{20}$ Third, those accused of engaging in sex with animals in cases that came to court were overwhelmingly young males from rural areas. These young men were often from marginalized populations. ${ }^{21}$ Let us explore if Russia conforms with these findings.

In Russia, there are several problems faced by a researcher attempting to search for and identify cases related to sexuality and sex crimes. At the beginning of this article, I gave a number of cases-101 incidents of skotolozhsvo-that have been identified during my systematic search in central and regional archives. I also pointed out that there are the same number of references to cases that did not survive or cannot be located in the records. ${ }^{22}$ The majority of cases come from secular state authorities, confirming that prosecution for sex with animals, despite the absence of explicit prohibition in secular law before 1716, was administered by secular prikazy (chancelleries) rather than by

Psykhologiia deviantnogo povedeniia (St. Petersburg: Rech', 2008); N. A. Isaev, Seksual'nye prestupleniia kak ob'ekt kriminologii (St. Petersburg: Iuridicheskii tsentr Press, 2007) and other literature on deviancy, perversions and deviant behavior.

${ }^{18}$ Miletski, "A History of Bestiality;" Hani Miletski, "Zoophilia: Another sexual orientation?" Archives of sexual behavior 46: 1 (2017): 39-42; Andrea M. Beetz, "Bestiality/Zoophilia: A Scarcely Investigated Phenomenon between Crime, Paraphilia and Love," Journal of Forensic Psychology Practice 4:2 (2004): 1-36.

${ }^{19}$ St. Basil 7 (Kormchaia, 1. 227)

${ }^{20}$ Ben-Atar and Brown, Taming lust; Collins, "Woman or Beast?"; Harvey, "Bestiality in Late-Victorian England”; cf. Fernández, “The Repression of Sexual Behavior” and Tortorici, Sins against nature.

${ }^{21}$ Ben-Atar and Brown, Taming lust; Collins, "Woman or Beast?".

${ }^{22}$ Russian archives rarely have subject indexes, and, if they do, they do not include subjects such as sexuality. These issues are contained within the "everyday" or "family" matters. Nineteenth-century Russian archival guides do contain detailed descriptions of collections. Soviet and post-Soviet guides mostly allocate records based on very broad categories and rarely go into any detail. The situation has improved with the advent of digitalization, but only a handful of regional archives have keyword searches available (for example, GAT or TsGIA SPb archives). Access to records is also complicated. 
ecclesiastical courts. The earliest case dates back to 1648. Eighty percent of cases, though, date from the eighteenth century, which is probably due to the better preservation of records from this period.

One hundred cases do not constitute a sizeable sum for a large country, such as Russia, Indeed, they only constitute 1 percent of all known sex crimes for the period between 1648 180o. This is consistent with other European countries with the exception of Sweden and Aragon. The German physician Dr. Hans Haustein, after an examination of Prussian court records for the years 1700 to 1730 , found that nine individuals were executed for bestiality and only three for homosexuality. ${ }^{23}$ Polly Morris found 27 prosecutions for bestiality (compared to 55 for sodomy) in Somerset courts (England) between 1740 and $1849 .{ }^{24}$ Arend $\mathrm{H}$. Huussen found only two mentions of bestiality in Frisian criminal court records between 1730 and $1811 .{ }^{25}$ P. G. Maxwell-Stuart discovered 77 cases of bestiality in Scotland for the period between 1570-1734, with 37 of these incidents occurring between $1654-1659$. $^{26}$

That was not the case of Sweden, Finland and Aragon. In Finland, Turku High Court alone dealt with 248 cases between 1728 and 1778 , amounts to 21 percent of all sex crimes during this period. ${ }^{27}$ In Sweden, the Royal Superior Court dealt with 1500 cases (including homosexuality) for the period between 1635-1754, which represents the largest amount of prosecutions in the early modern period. Jonas Liliequist notes that execution for bestiality comprised 25-30 percent of all executions in Sweden. ${ }^{28}$ The Aragonian Inquisition (Spain) managed to prosecute 492 cases between 1560-1700, which accounted for 27 percent of all known sex crimes for the period. ${ }^{29}$

The difference between rare prosecutions in Europe, including Russia, and en masse prosecutions in Sweden/Finland and Aragon is striking. Once explanation has to do with the environmental framework of prosecutions. It is clear that geography somehow plays a role here. In Russia, the majority of cases come from the north or north-west (46 percent) and nearly one-third of all cases (31 percent) derive from Siberia (Tobol'sk, Orenburg, Perm, Eniseisk etc.). Moreover, in the nineteenth century in one Siberian region (Tomsk), state courts dealt with 111 cases of skotolozhstvo for the twenty-five-year period between 1836-1861..$^{30}$ Coupled with the data above, we can conclude that sex with animals was much more visible and more frequently prosecuted in the north of Europe or in the Global North as Aragon is situated in the northeast of Spain. Sex with animals came to the attention of the authorities due to witness reports..$^{31}$ In Russia, the absolute majority of cases (except our opening case) were prosecuted upon the report of a witness who caught the perpetrator in the act, with many of the witnesses being owners of the abused animals. It might be

\footnotetext{
${ }^{23}$ James D. Starkey, "Sodomy in Enlightenment Prussia: From Execution to Suicide," in The Pursuit of Sodomy: Male Homosexuality in Renaissance and Enlightenment Europe, ed. Kent Gerard and Gert Hekma (New York: Routledge, 1989), 164.

${ }^{24}$ Polly Morris, "Sodomy and Male Honour: The Case of Somerset, 1740-1850," in Ibid., 389.

${ }^{25}$ Arend H. Huussen, Jr., "Prosecution of Sodomy in Eighteenth Century Frisia, Netherlands," in Ibid., 257.

${ }^{26}$ P. G. Maxwell-Stuart, "'Wild, Filthie, Execrabil, Detestabill, and Unnatural Sin': Bestiality in Early Modern Scotland," in Sodomy in Early Modern Europe, Thomas Betteridge (Manchester: Manchester University Press 2002), 89 .

${ }^{27}$ Keskisarja, "Secoituxesta Järjettömmäin Luondoccappalden Cansa".

${ }^{28}$ Jonas Liliequist, Brott, Synd och Straff. Tidelagsbrottet i Sverige under 160o- och 170o-talet. Ph.D. dissertation (Umea University, 1991), 395.

${ }^{29}$ Fernández, "The Repression of Sexual Behavior by the Aragonese Inquisition between 1560 and 1700".

30 Nikolai Kostrov, Iuridicheskie obychai krest'ian-starozhilov Tomskoi gubernii (Tomsk: Tomskaia gubernskaia tipografiia, 1876), 76 .

${ }^{31}$ Fernández, "The Repression of Sexual Behavior by the Aragonese Inquisition between 1560 and 170o"; Tortorici, Sins against nature; Keskisarja, "Secoituxesta Järjettömmäin Luondoccappalden Cansa" and other authors.
} 
argued that colder climate prompted men to have sex with animals indoors in the northern parts of Europe (and in the Global North). An absolute majority of incidents took place in barns and stables, which carried with it the obvious risk of getting caught. In my database, only three cases took place in a field or a forest, but not far enough from the settlement. In warmer climates, sex with animals could and did take place in fields and remote areas, which decreased the chances of any witnesses being present. ${ }^{32}$

The discrepancy in numbers can also be examined by taking a closer look at perpetrators, as the assumption is that it was predominantly young males from marginalized populations (laborers) who experimented with their sexuality and committed assault on animals as a part of this experiment, and did not take necessary precautions to in order to avoid being caught. Russian data shows that 50 percent of all offenders were peasants, while 23 percent were in the military. This is consistent with Finnish and Swedish data. In Finland, 23 percent of those accused of sexual crimes were in the military, 29 percent were laborers and 32 percent were farmers (including 17 percent designated as being farmers' sons). ${ }^{33}$ Swedish data shows that almost 60 percent of offenders were laborers, followed by 12 percent who were in the military. ${ }^{34}$ Scholars often theorize about sex with animals as a formative experience for younger males in defining their sexuality or as an aspect of being single. The data seems to support this characteristic of the perpetrators. In Finland, 6o percent of perpetrators were young males below the age of $20 .{ }^{35}$ In Sweden adolescents (younger than 20) comprised 49 percent of all those who were accused, while those in their twenties accounted for $34 \% .^{36}$ Maxwell-Stuart has noted the age discrepancy between the accused and the witnesses: the majority of the accused were younger than 20, whereas the majority of witnesses were between 40 and $50 .{ }^{37}$ However, the perpetrators in Russia were older than in Sweden and Finland, being in their twenties but with a sizeable number of men from older age groups. The oldest offender was 85 . Andrei Ostafiev, a retired dragoon from Orenburg, attempted to have sex with a heifer, but was interrupted by his great-grandson. ${ }^{38}$ Only 10 percent of perpetrators were younger than twenty. However, two thirds of these men were unmarried.

None of the perpetrators, though, abused their own animals. All the peasants in the database were laborers working for someone else. Hence, they abused their masters' animals or the animals they tended to. Only one soldier abused a mare belonging to his commander. ${ }^{39}$ Other soldiers abused a female goat, a female dog and cows belonging to local peasants. However, such a predominant number of laborers and soldiers was mostly likely prosecuted because they were caught and reported by the owners of the animals. The owners would hardly report themselves. At the same time, those at the bottom of the social ladder would probably think about their decision to bring such an accusation, especially, if it carried the risk of them ending up in a situation where it was simply their word against that of their master.

Such reports would only come to the attention of the authorities in cases when social standing could be leveraged, One such case took place in 1749 in Tobol'sk when a local

\footnotetext{
${ }^{32}$ See also the discussion in Fernández, "The Repression of Sexual Behavior by the Aragonese Inquisition between 1560 and $1700 . "$

${ }^{33}$ Keskisarja, "Secoituxesta Järjettömmäin Luondoccappalden Cansa," 113.

${ }^{34}$ Liliequist, Brott, Synd och Straff, 51.

${ }^{35}$ Keskisarja, "Secoituxesta Järjettömmäin," 123.

${ }^{36}$ Liliequist, Brott, Synd och Straff, 49.

${ }^{37}$ P. G. Maxwell-Stuart, “'Wild, Filthie, Execrabil, Detestabill, and Unnatural Sin'," 87.

${ }^{38}$ RGIA, f. 796, op. 81, d. 31, 11. 93-93 ob.

${ }^{39}$ Rossiiskii gosudarstvennyi voenno-istoricheskii arkhiv (hereafter RGVIA), f. 8, op. 3/92, d. 968.
} 
clergyman-Semyon Nikitin-was caught in the act of having sex with his mare by another clergyman-Efim Narygin. Narygin happened to be riding through the forest, on his way to their village, when he saw Nikitin's mare and stopped to greet his colleague. At this time he noticed that Nikitin was "committing filth" with his mare. Narygin reported the incident to their priest-Petr Ikonnikov, who, in turn, reported the incident to the local bishop. There were no other witnesses and the whole trial ended up being Narygin's word against that of Nikitin. The latter insisted that he no longer owned a mare, as his horse has died the previous summer. Nikitin also accused Ikonnikov of making Narygin come forward with a false complaint, because he bore a grudge against him. The court ordered Nikitin and Narygin to have a face-to-face confrontation (ochnaia stavka). During this direct confrontation Nikitin confessed and was consequently defrocked and sentenced to corporal punishment. ${ }^{40}$

It would not have been easy to carry such an accusation through to its conclusion using the court system and community support for laborers' claims, if it happened to be made against their masters. Laborers were always suspected of looking for opportunities to damage their masters' property. It might be implied that committing sex with a master's animal (mostly cows) could be a way of getting at their employers for other abuses or just out of spite to damage the cattle. Such motivations made sex with animals a property crime. ${ }^{41}$ The abused animal had to be killed as per the ruling laid out in the Old Testament Book of Leviticus. Thus, the owner of the animal suffered financial loss and other consequences (such as losing a source of milk and food). The court always looked into property damage as a motive by conducting reputational assessments and asking specifically if there had been a prior conflict or whether anyone had any knowledge of relationships between the accused and his accuser. None of the cases revealed any prior conflicts between a laborer and his master. Moreover, the laborers were often positively characterized by their masters and neighbors, to whom such an act was almost always a shock. In 1798, while working on his son-in-law's farm, Grigorii Burlak had sex with a mare and was caught by his son-in-law in the act. The whole village (in the Podol'sk region) could not quite understand why he would act as he had. During house-to-house questioning, everyone characterized Grigorii as a good neighbor and a family man. Some people referred to his old age (he was 77) and hinted that his mental faculties had just failed him. Bartok, his son-in-law, could not come up with any reason; he explained to the authorities that they had good relationships and he, Bartok, treated his wife (Burlak's daughter) very well, ruling out any possible family conflict. ${ }^{42}$

Besides, the court routinely ruled to compensate the owner accordingly. The amount of compensation was viewed to be sufficient if it enabled the victim to buy a new animal. In 1692, one Bazhenko, a laborer in Galich uezd, assaulted a black cow that belonged to the local coachman (iamshchik). The court ordered that the cow should be killed and buried in an "unknown" place as per apostolic rules. Tereshka, the owner, explained that his family

\footnotetext{
${ }^{40}$ Gosudarstvennyi arkhiv v g. Tobol'ske (hereafter GAT), f. 156, op. 1, d. 519.

${ }^{41}$ See Chapter 5 in Christine Ekholst, A Punishment for Each Criminal: Gender and Crime in Swedish Medieval Law (Leiden: Brill, 2014), 151-189; and discussion in Beetz, "Bestiality/Zoophilia"; Beirne, "Rethinking bestiality”; Collins, "Woman or beast?”; James Gacek and Richard Jochelson, "Placing 'Bestial' Acts in Canada: Legal Meanings of 'Bestiality' and Judicial Engagements with Sociality," The Annual Review of Interdisciplinary Justice Research 6 (2017): 236-261.

${ }^{42}$ Rossiiskii gosudarstvennyi istoricheskii arkhiv (hereafter RGIA), f. 796, op. 79, d. 913. The court often enquired about relationship within the family when family members were involved. Asking about proper treatment of a wife when a father-in-law and a son-in-law were involved, was a routine enquiry. On this see in detail: Marianna Muravyeva, “Till Death Do Us Part': Spousal Homicide in Early Modern Russia," The History of the Family 18 (2013): 306-330.
} 
would go hungry without the cow. In compensation, he was awarded two rubles in damages, precisely the price of the new cow. ${ }^{43}$ By the end of the eighteenth century, the compensation awarded included not only the price of an animal, but also lost profits as in the 1794 case from St. Petersburg. The court decided that damages amounted to 19 rubles, considering that the abused cow, killed by now, belonged to the profitable estate. ${ }^{44}$ Therefore, while the cases show elements of property damage crime, having sex with an animal was a very compilated way of revenge by inflicting property damage as it resulted in payment obligations for the perpetrator.

As the material shows, the most problematic aspect of studying sex with animals is establishing the motive of such behavior. Not all perpetrators explain themselves, but when they do, the absolute majority cite alcohol and various degrees of intoxication as their excuse. This was often followed by genuine remorse and offers to compensate for the damaged animal. In 1722 the Admiralty in St. Petersburg employed Evsei Zhukov as a stovemaker (pechnik). He had sex with a cow belonging to a fellow stovemaker and was caught by two laborers in the act. Zhukov, who exhibited remorse throughout his trial, insisted that he was so drunk he could not possibly understand what he was doing and immediately offered to compensate for any damages. ${ }^{45}$ In the above-mentioned cases of Bazhenko and Burlak, they both claimed they were too drunk to understand their actions. In almost 70 percent of the cases, alcohol figured as an excuse for mental deficiency. In the seventeenth century, Russian law treated intoxication as a mitigating circumstance. ${ }^{{ }^{6}}$ In the meantime, moral and didactical literature harshly denounced drinking. It made a direct link between drinking and committing various sins, thus treating alcohol consumption as a precondition for sinful behavior. ${ }^{47}$ Apparently, moral literature responded to widespread drinking in early modern Russian society. ${ }^{48}$ At the same time, alcohol functioned as a convenient and universal explanation for the possibility of committing such an immoral crime. Accepting other motivations meant recognizing the possibility of an individual consciously breaking natural law and even revolting against it, which not only seemed impossible, but apocalyptic at the time. ${ }^{49}$ Russian courts, therefore, gladly accepted intoxication as an explanation and proceeded with awarding compensation, corporal punishment and penance. It was important for the community to receive the message that this type of "filth" was not threatening as it lacked malicious intent, so that their animals were safe and religious and societal boundaries were observed. The perpetrators also were

\footnotetext{
${ }^{43}$ NLR, Manuscripts department, f. 532, op. 1., no. 3720, ll. 1-7.

${ }^{44}$ Tsentral'nyi gosidarstvennyi istoricheskii arkhiv Sankt-Peterburga (hereafter TsGIA SPB), f. 1716, op. 1, d. 1765, 1. 2, 6-6ob.

${ }^{45}$ RGADA, f. 285, op. 1 ch. 6, kn. 1904, d. 83; RGIA, f. 796, op. 2, d. 67.

46 "Sobornoe Ulozhenie 1649 goda," in Akty zemskih soborov, ed. A. G. Man'kov (Moscow: Iuridicheskaia literatura, 1985), XXII: 17.

${ }^{47}$ On the dangers of drinking, see the classic sixteenth-century homily "On Drinking" in Izmaragd (A Jewel), a popular compilation of moral works, in Biblioteka literatury Drevnei Rusi, available at http://lib2.pushkinskijdom.ru/tabid-5144. Accessed July 29, 2019.

${ }^{48}$ In the late 1640 s, Russia experienced "tavern mutinies," that is, urban riots against rising alcohol prices. The authorities insisted that harvests would suffer due to mass drinking at Easter, when peasants were supposed to work in the fields, but drank instead. This resulted in the summoning of a special Land Assembly that prohibited drinking and selling alcohol during church holidays. See I. Gurvich et al., Upotreblenie alkogolia v Rossii: istoriia, statistika, psikhologiia (St. Petersburg: Izd-vo St. Petersburgskogo universiteta, 2008); V. Sokolov, 'P'ianstvo na Rusi v epokhu pervykh Romanovykh i mery bor'by s nim,' Golos minuvshego 9 (1915): 105-118.

${ }^{49}$ On gender, drinking and crime also see Marianna Muravyeva, "Family authority, violence against parents, and parricide in Russia, 1600-180o," Journal of Family History 41, no. 3 (2016): 294-317.
} 
either too young or too old or too drunk to understand what they were doing. These attitudes are evident in official legal and moral discourses on sex with animals that are analyzed in the following sections.

\section{"Lying with an Animal" (skotolozhstvo): Legal and Moral Attitudes to Sex with Animals in Early Modern Russia}

The narratives of the crime of skotolozhstvo provide enough evidence to examine official and communal approaches to interspecies copulation. Russian court narratives are rather concise and focus on what kind of act was committed rather than how it was administered. Those narratives were also generated by a variety of clerks, who not only wrote down interrogations and witness statements, but also translated their words into legally appropriate language. All these narratives follow a certain form: an initial petition or report, investigational record, witness interrogations, digest of relevant laws, final judgment and confirmation of the execution of a sentence. ${ }^{50}$ Not all the court cases I have studied are complete; in fact, the older the case, the more incomplete it is. However, in combination with other legal sources they provide a cohesive picture of how sexuality, abuse and nature were intertwined in legal approaches to criminalized sexualities.

In the seventeenth and eighteenth centuries, sex with animals was punishable by the death penalty all over Europe and Colonial America. ${ }^{51}$ However, none of the Russian cases involved the death penalty as a final sentence for sex with animals. Russia appears to be the only country that did not apply this punishment to those convicted of interspecies sex. In the cases of skotolozhstvo that came to the attention of judges the accused were sentenced to penal labor in a monastery in the seventeenth century and corporal punishment in combination with penance and penal labor in the eighteenth century. While secular law did not contain any punishment for sex with animals until 1716 , we are able to learn about penalties from the case files. Every case file examined in the present study contained a special extract with appropriate excerpts from existing laws in order to justify the imposition of the designated punishment. The extracts occurred in in the following order: the Kormchaia book and other ecclesiastical references (mostly Nomocanons) in the seventeenth century; the Military Code of 1716 and the Naval Code of 1720 in the eighteenth century; and then royal and governmental executive ordinances and edicts. It is instructive to compare these lists of extracts with existing legislation at the time in order to see how judges perceived the hierarchy of laws and if they applied the law selectively or followed certain patterns in prosecuting the same crime. In cases of sex with animals, the lists are almost identical, notwithstanding the jurisdiction of these prosecutions.

In Russia, sexual transgressions outlined in the Bible were prosecuted under ecclesiastical jurisdiction based on the Kormchaia, which contained not only ecclesiastical norms but Roman law in its Byzantine interpretation..$^{52}$ Before the early 1700 , Russia had maintained separate church and state jurisdictions. ${ }^{53}$ The Kormchaia book had served as the codex juris canonici of the Russian Orthodox Church since the Middle Ages and

\footnotetext{
${ }^{50}$ Muravyeva, "Russian Law in the Early Modern Period."

${ }^{51}$ On perceptions of sex with animals as a crime of "bestiality", see Graham Parker, "Is a Duck an Animal?: An Exploration of Bestiality as a Crime," Criminal Justice History 7 (1986), 95-109; Marianna Muravyeva, "Sexual Variations," in A Cultural History of Sexuality: A Cultural History of Sexuality in the Enlightenment, ed. By Julie Peakman (Oxford: Berg, 2010), 85-106.

${ }^{22}$ Marianna Muravyeva, "Sex, crime and the law: Russian and European early modern legal thought on sex crimes," Comparative Legal History 1, no. 1 (2013): 75-103.

${ }^{53}$ Muravyeva, "Russian Law in the Early Modern Period."
} 
contained enough entries to justify punishment for sex with animals. Mosaic Law insisted on the death penalty, but Russian ecclesiastical courts never directly applied Mosaic rules. More often, they relied on apostolic canons and the rules of the church fathers, as well as the Procheiros Nomos and decisions of church councils. ${ }^{54}$ According to the rules of the Council of Ancyra, punishment for sex with animals-excommunication-had to be meted out based on age and marital status ( 15 years for those younger than 20 years of age; 25 years for those older than 20 and who were married and life for those older than 50 and who were married) (Ancyr. 16). The Procheiros Nomos, being a secular code of Byzantine emperors, added castration as a punishment. ${ }^{55}$ Penances imposed by the church fathers and councils focused not only on rehabilitating the soul, but on cleaning the body from abuse as they included strict dieting and physical exercise in the form of penal labor. ${ }^{56}$ That what happened to one Bazhenko Gerasimov from Galitch uezd, who committed "filth" with a cow in 1692 and was sentenced to penance in a monastery "under command" (pod nachal) ${ }^{57}$ which meant he was placed at the disposal of the monastery's authorities, so they can use him and other convicts where needed so they could perform necessary religious and spiritual purification..$^{8}$

In cases involving sex with animals, church and state jurisdictions complimented each other when punishment was concerned. Secular and ecclesiastical punishments would supplement each other (for example, corporal punishment and penances), while several secular punishments would be reduced to the harshest or mildest sentences based on age, gender, social status and penal status (first crime and reputation) of the perpetrator. ${ }^{59}$ When looking at how punishments were defined, we find that state law took responsibility for the flesh as judges imposed secular punishments (imprisonment, corporal punishment or fines); and ecclesiastical law was concerned with the soul by defining the terms of penance. The average penance and excommunication periods varied between three and twenty years, mostly following the rules of the Council of Ancyra, but were often reduced as case files show. ${ }^{60}$ In the 1793 case of attempted skotolozhstvo by Arkhip Potapov, which originated in the equity court (sovestnyi sud) as the accused had just turned fifteen, it was decided to send him to a monastery for six months to do his penance so that "he would have enough time to repent such a deed that was contrary to God and to clean his conscience and soul." ${ }^{\prime 1}$ The judges deliberated that his age and "simple mind" pushed him to commit such a deed that was "contrary to God." Potapov confessed and hence his penance was significantly reduced (which also followed the Synod's regulations of 1781 on

\footnotetext{
${ }^{54}$ Muravyeva, "Sex, crime and the law."

${ }^{55}$ Kniga glagolemaia Kormchaia (Moscow, 1653) (hereafter Kormchaia), 1l. 47-470b., 492. See also, A. S. Pavlov, Nomokanon pri Bol'shom Trebnike (Odessa: tip. G. Lissnera and A. Geshelia, 1872), 66; National Library of Russia (hereafter NLR), Manuscripts Department, f. 775, no. 2060, 1. 110b.; f. 573, SPBDA 130, 1. 21.

${ }^{56}$ S.O. Shaliapin, Tserkovno-penitentsiarnaia Sistema v Rossii XV-XVIII vekov (Arkhangel'sk: IPTs SAFU, 2013), 90-131.

${ }^{57}$ NLR, Manuscripts department, f. 532, op. 1., no. 3720, 11. 4-6ob.

${ }^{58}$ See descriptions of what was included in the "pod nachal" penance in a monastery: Shaliapin, Tserkovnopenitentsiarnaia Sistema, 100-105; B. B. Gazenvinkel', "Epitimshschiki i kolodniki Kondinskogo monastyria," Kalendar' Tobol'skoi Gubernii za 1890 god (Tobol'sk, 1889), 264.

${ }^{59}$ Marianna Muravyeva, "Russian Early Modern Criminal Procedure and Culture of Appeal," Review of

Central and East European Law 38 (2013): 295-316.

${ }^{60}$ On criminal procedure for sex crimes, see Muravyeva, "Russian Early Modern Criminal Procedure and Culture of Appeal."

${ }^{61}$ Tsentral'nyi gosidarstvennyi istoricheskii arkhiv Sankt-Peterburga (hereafter TsGIA SPB), f. 19, op. 1, d. 15861, 1. 1ob.
} 
penances imposed by equity courts). ${ }^{62}$ He was also exempted from corporal punishment as he was still a minor.

However, the administration of penance could be a confusing and problematic duty. In 1779, Petr Serebrennikov, a priest from one of the village churches in the diocese of Tobol'sk, asked his bishop to direct him to references in the Kormchaia about penance for killing animals as a result of having sex with them. He complained that he could not find proper rules anywhere. During his confession an unnamed parishioner shared that he practiced sex with chickens and that two birds had been killed as a result. The parishioner was truly remorseful and asked for a penance for killing these birds. Serebrennikov was very confused by this confession and had to consult with his bishop as to what penance to impose for killing birds. The bishop pointed out that the penance-excommunicationshould be imposed for having sex with the birds. According to St. Basil's seventh rule and the sixteenth rule of the Council of Ancyra rule 16, this should amount to fifteen years of penance. The bishop explained to Serebrennikov that birds did belong to the category of "animals," so the penance was warranted. In 1781, Serebrennikov reported back on the progress of the penance. ${ }^{63}$

Secular law was rather ambiguous regarding punishment for sex with animals. The first secular code to include it was the Military Code of 1716, in which Peter I attempted to create a model for further codification of Russian law. It included art. 165: "he who lies with an animal or other senseless creature should be given harsh corporal punishment." 64 Originally, in its draft stage, the Military Code followed the Swedish model and stated that "he [the perpetrator] is to be beheaded and, together with an animal with which [he] was involved, is to be placed in a log box (srub) to burn." ${ }^{65}$ Yet, Peter I personally removed capital punishment that derived from Leviticus (20:15-16) ${ }^{66}$ and substituted it with corporal punishment. The same was done for other sex crimes, including same-sex relations and rape. Peter reserved the death penalty as an alternative to penal labor for life only for those sexual practices that included the use of violence. ${ }^{67}$ In Peter's view, none of the consensual types of fornication (blud) warranted the death penalty, which took sex with animals (and other "senseless creatures") outside of the scope of consent. Peter's wording also differed from the Bible and the Kormchaia in defining what "skot" (an animal) is. In religious documents, beasts are translated as "four-legged animals" to the exclusion of other nonhuman forms. In Peter's version, the word skot, which denotes any animal, ${ }^{68}$ and the phrase

\footnotetext{
${ }^{62}$ Polnoe sobranie postanovlenii i rasporiazhenii po vedomstvu pravoslavnogo isopvedaniia Rossiiskoi Imperii, series III (hereafter PSPR III) (St. Petersburg: v Sinodal'noi tipografii, 1906-1915), vol. 2, N 1019.

${ }^{63}$ GAT, f. 156, op. 3, d. 1737.

64 “Artikul Voinskii," in A. G. Man'kov, ed., Zakonodatel'stvo perioda stanovleniia absolutizma (Moscow: Iuridicheskaia literatura, 1986), 358.

${ }^{65}$ N. A. Voskresenskii, Zakonodatel'nye akty Petra I (Moscow-Leningrad: Izd-vo AN SSSR, 1945), 49.

${ }^{66}$ Citation: "And if a man lie with a beast, he shall surely be put to death; and ye shall slay the beast. And if a woman approach unto any beast, and lie down thereto, thou shalt kill the woman, and the beast: they shall surely be put to death; their blood shall be upon them" (20:15-16). See the Old Russian version, cit. according to the Elizabethan Bible of 1751, Biblia, siriech knigi sviashchennago pisaniia vetkhago i novago zaveta (St. Petersburg: s.n., 1751), vol. 1, 185: И иже аще даст ложе свое четвероножному, смертию да оумрет, четвероножное же оубиете. И жена яже аще приступит ко всякому скоту, еже быти с ним, да оубиете жену и скот, смертию аумрут, повинни суть." (“I izhe ashche dast loze svoe chetveronozhnomu, smertiiu da oumret, chetveronozhnoe zhe oubiete. I zhena iazhe ashche pristupit ko vsiakomu skotu, ezhe byti s nim, da oubiete zhenu i skot, smertiiu aumrut, povinni sut'.")

${ }^{67}$ Ibid. See also Marianna Muravyeva, "Personalizing homosexuality and masculinity in Early Modern Russia," in Gender in Late Medieval and Early Modern Europe, ed. Marianna Muravyeva and Raisa Toivo (London: Routledge, 2013), 217-236.

${ }^{68}$ Slovar' russkogo iazyka XI-XVII vekov (Moscow: Nauka, 1975-2006), vol. 25, 7-9.
} 
"other senseless creatures" was used to stress the inability to give consent due to their senselessness.

Russian legal provisions mirrored early modern debates on relationships between ecclesiastical (canon) and secular (state) law in the situation when early modern states proceeded to create universal jurisdictions and legal spaces for its subjects. All early modern legal commentators agreed that it was a crime against nature, so the object of infringement was nature and relations connected to it. ${ }^{69}$ In this case, nature might have meant different things, but, Christian legal thought notwithstanding, all denominations relied on St. Thomas Aquinas (1225-1274). He considered sins against nature to be a specious of lust, since such acts were carried out solely for the pursuit of venereal pleasure and excluded procreation. They therefore differed from other sins of lust, such as fornication, adultery, seduction, rape and incest, not only because they were contrary to right reason, but they were also contrary to "the natural order of the venereal act as becoming to the human race." For Aquinas, the sin against nature included four different activities: 1 ) procuring ejaculation (pollutio) without any copulation, that is, masturbation; 2) copulation with a thing of undue species, and this is called "bestiality" (si fiat per concubitum ad rem non eiusdem speciei, quod vocatur bestialitas); 3) copulation with an undue sex (concubitus ad non debitum sexum); 4) deviation from the natural manner of copulation. "Bestiality" was named as the most grievous sin, because "use of the due species is not observed" (Gravissimum autem est peccatum bestialitatis, quia non servatur debita species). ${ }^{70}$

Aquinas provided a legal, moral and scientific framework for dealing with humananimal relationships with a focus on desire as its central component. Medieval and early modern Russian thought generally followed the generic Christian European tradition in this respect. Medieval and early modern commentators repeated the hierarchy created by God as described in Genesis (1:26) by which a man, made in God's image and after God's likeness, became master over cattle, fowl, fish and "over every creeping thing that creepeth upon the earth." 71 Despite Adam's fall, he preserved his status as "master" over other species. There are certain interpretations of Adam's time in Eden before Eve was created. Some commentators in the Hebrew version suggested that Adam went through all the other species before he realized that they did not fit together. ${ }^{72}$ This could probably explain

${ }^{69}$ See the following seventeenth-century and eighteenth-century commentators: Sir Edward Coke, Institutions of the Laws of England (London: W. Rawlins, 168o), Part III, 58-59; Pierre Francois Muyart de Vouglans, Les Loix Criminelles de France, dans leur ordre naturel, etc. (Paris, 1780), 244; Gaston DuboisDesaulle, Etude sur la bestialité au point de vue historique, médical et juridique (Paris: Charles Carrington, Libraire-Éditeur, 13, Faubourg Montmartre, 1905), 227; William Blackstone, Commentaries on the Laws of England (Philadelphia, 1893), vol. II, 215-216. See also, Murrin, “'Things Fearful to Name': Bestiality in Colonial America"; Muravyeva, "Sex, crime and the law."

${ }^{70}$ St. Thomas Aquinas, Summa Theologica, ed. par J.-P. Migne (Paris, 1859), vol. 3, 1118-1119 (II-II, Q. CLIIIICLIV). See also Vern L. Bullough, Sexual Variance in Society and History (New-York: John Wiley \& Sons, 1976), 380-381. Here Bullough gives a slightly different translation (copulation with nonhuman creatures), which changes the connotation of the act.

${ }^{71}$ See the Russian version in Biblia, siriech knigi sviashchennago pisaniia vetkhago $i$ novago zaveta (St. Petersburg: s.n., 1751), vol. 1, 3: "И рече Бог: сотворим человека по образу нашему и по подобию: и да обладает рыбами морскими, и птицами небесными, [и зверми,] и скотами, и всею землею, и всеми гады пресмыкающимися по земли." ("I reche Bog: sovtvorim cheloveka po obrazu nashemu i po podobiiu: i da obladaet rybami morskimi, i ptitsami nebesnymi, [i zvermi,] i skotami, i vseiu zemleiu, i vsemi gady presmykaiushchimisia po zemli.")

${ }_{72}$ See Harry Fox (Lebeit Yoreh), "Biblical Recognition: Separation From Bestiality and Incestuous Relationships as Resistance to Hellenization," in Recognition and Modes of Knowledge: Anagnorisis from 
why mythology and folklore humanized animals and other non-human creatures by allowing them to speak, think and feel. Russian bestiary tradition often explored humananimal relations in communication between the two, ${ }^{73}$ which also provides a useful framework for treating sexual encounters with animals as a certain type of communication. In compilations, such as Physiologus (Fiziolog), entries for various animals, birds and "creepers" include religious and moral advice to follow or avoid certain features or description of behaviors that are associated with certain animals. After the entry for "woodpecker," the moralist commentary is about how the devil behaves: if he finds weakness in man he nests there immediately, if he finds strength he escapes. ${ }^{74}$

Drawing on the medieval tradition of attitudes to animals and other non-human creatures, nature emerges as a framework of logic that allows only specific communication within a hierarchical model of how moral and natural philosophers saw the world. This model was teleological, eventually with the higher goal of serving God and reflected the contemporary feudal organization of society with its strict boundaries between various social groups. ${ }^{75}$ In this teleology, humans may communicate with other species, but only for the purposes allowed by God to serve Him. This model might not have corresponded with everyday practices or folk interpretation of their environment, but it was embedded in legal and moral provisions of early modern Europe, which created strict regulations and harsh prosecutions for those who crossed these boundaries. ${ }^{76}$

\section{Animals and Humans: Observing the Boundaries of Humanity}

One of the feared consequences of crossing the boundaries between species was the production of cross-species hybrids or monsters. Sex with animals was a male crime: a hundred percent of offenders in Russia and other countries were male and they mostly committed abuse on female animals: heifers, cows and mares. As a result, the whole discourse around sex with animals was focused on the possibility of impregnating a female animal and contaminating another species' process of reproduction.

According to Jonas Liliequist, the major concern for Swedish authorities was that of producing hybrids or monsters. Analyzing the Swedish cases of sexual intercourse between a demon (such as a water nymph or a forest ghost) and a man (rarely a woman), Liliequist

Antiquity to Contemporary Theory, ed. Teresa G. Russo (Edmonton: University of Alberta Press, 2013), 77-100; Saul M. Olyan, “'And with a Male You Shall Not Lie the Lying down of a Woman': On the Meaning and Significance of Leviticus 18: 22 and 20: 13," Journal of the History of Sexuality 5, no. 2 (1994): 179-206.

73 Tatiana Chumakova, "Simvolika zhivotnykh v khristianskoi kul'ture," Chelovek 3 (2009): 93-104.

${ }^{74}$ Fisiolog (Physiologus), ed. E. Vaneeva and L. Dmitriev (St. Petersburg: Nauka, 1996). See also, Aleksandr Iurchenko, Aleksandriiskii 'Fiziolog': Zoologicheskaia misteriia (St. Petersburg: Evrazia, 2001). On animalhuman relations with the focus on witchcraft in seventeenth-century Russia, see Charles J. Halperin and Ann M. Kleimola, "Humans as Animals, Animals as Humans in Seventeenth-Century Russia," ВИВЛІОӨИКА: ЕJournal of Eighteenth-Century Russian Studies 6 (2018): 46-57.

75 On Aquinas' model and feudalism, see Chapter 1 in Hans Fink, Social Philosophy (RLE Social Theory) (London: Routledge, 2014), 6-20.

${ }^{76}$ For more on the evolving field of animal-human relationships and subjectivities in the early modern period, as well as examples of works that chart the gradual breakdown of barriers that strictly divided humans and animals, see Erica Fudge (ed.), Renaissance Beasts: Of Animals, Humans, and Other Wonderful Creatures (Chicago: University of Illinois Press, 2004); Keith Thomas, Man and the Natural World: A History of the Modern Sensibility (New York: Pantheon Books, 1983); Erica Fudge, Brutal Reasoning: Animals, Rationality, and Humanity in Early Modern England (Ithaca: Cornell University Press, 2006); Nathaniel Wolloch, Subjugated Animals: Animals and Anthropocentrism in Early Modern European culture (Amherst, NY: Prometheus Books, 2006); Adrian Franklin, Animals and Modern Cultures: A Sociology of Human-Animal Relations in Modernity (London: Sage, 1999). 
shows that judges associated these cases and tried them on the count of bestiality rather than witchcraft. This magic-bestiality connection was reaffirmed with the idea that witches usually copulated with the devil in animal form (often a dog) ${ }^{77}$ In other countries, sex with animals often came to light in witchcraft cases or theological writings on demonology. ${ }^{78}$ The connection between diabolical sex and the conception and delivery of hybrid creatures was also a part of Russian magical and demonic beliefs. ${ }^{79}$ However, Russian judges did not feel any inclination to theorize about it until at least the late eighteenth century. Thus, we cannot know if they believed in these ideas at all. Russian seventeenth-century documents do provide descriptions of women having sex with demons, which supposedly resulted in the birth of an animal or deformed offspring. The Tale of Possessed Solomonia (Povest o besnovatoi zhene Solomonii) is the best-known example among them. ${ }^{80}$ How much of this literature made it to actual beliefs at the community level is hard to assess. In witchcraft cases, such a connection could be made easily as both scholars and sources provide ample evidence. ${ }^{81}$ Moreover, Russia had a developed popular demonology that was different from theological theories regarding witchcraft. ${ }^{82}$

Court records, especially from the seventeenth century, give a very concise account of the crime. None of the cases directly mentions any diabolical intervention. The only thing we learn is that cows, but not other abused animals, were killed and their owners duly compensated. This was connected with the fear of defiled cow's milk and concerns that this milk might now be the result of a monster's conception, which was seen as an unlawful breach of natural law rather than the devil's work.

In the 1779 case of attempted sex with a cow from St. Petersburg, an owner of a cow (also a principal witness who prevented the actual intercourse) stated that since the time he caught his laborer in the act he never used milk from the cow in question. ${ }^{83}$ In all the cases involving cows, cow's milk was treated as resembling women's milk, that is, it was only allocated for feeding their own species' offspring and was never used by anyone else. In such cases, a cow's flesh was also transformed and ceased to be regarded as being something appropriate to consume. These anxieties can be seen in the court records, depositions, cross-examinations and house-to-house questionings. At the same time, in cases of a mare being abused (and a female goat and a bitch) nobody expressed any anxiety

\footnotetext{
77 Jonas Liliequist, "Sexual Encounters with Spirits and Demons in Early Modern Sweden: Popular and Learned Concepts in Conflict and Interaction," Christian Demonology and Popular Mythology 2 (2006), 160165; Liliequist, "Peasants against Nature," 408-411.

${ }^{78}$ Maxwell-Stuart, “Wild, Filthie, Execrabil, Detestabill, and Unnatural Sin'.”

${ }^{79}$ Halperin and Kleimola, "Humans as Animals, Animals as Humans in Seventeenth-Century Russia."

${ }^{80}$ On demonology see: A. V. Pigin, Iz istorii russkoi demonologii XVII veka (St. Petersburg: Dmitrii Bulanin, 1998); D. I. Antonov, M. R. Mizuls, Demony i greshniki v drevnerusskoi ikonografii (Moscow: Indrik, 2011 ); A. Korolev, I. Maier, S. Shamin, "Sochinenie o demonakh iz arkhiva Posolskogo prikaza: k voprosu o kul'turnykh kontaktakh Rossii i Evropy poslednei treti XVII stoletiia,” Drevniia Rus'. Voprosy medievistiki 4 (2009): 108121.

${ }^{81}$ For the most recent book on witchcraft in seventeenth century Russia, see Valerie Kivelson, Desperate Magic: The Moral Economy of Witchcraft in Seventeenth-Century Russia (Ithaca: Cornell University Press, 2013). For eighteenth-century Russia, see Elena Smilianskaia, Volshebniki, Bogokhul'niki, Eretiki: Narodnaia religioznost' i dukhovnye prestupleniia v Rossii XVIII v. (Moscow: Indrik, 2003); A. S. Lavrov, Koldovstvo $i$ religiia $v$ Rossii 1700-1740 gg. (Moscow: Drevlekhanilishche, 2000).

${ }^{82}$ See the discussion of literature in Marianna Muravyeva, "Russian Witchcraft on Trial: Historiography and Methodology for Studying Russian Witches," in Writing Witch-Hunt Histories: Challenging the Paradigm, ed. Marko Nenonen and Raisa Maria Toivo (Leiden: Brill, 2014), 109-139.

${ }^{83}$ TsGIA SPB, f. 1740, op. 1, no. 19, 1. 1rev.
} 
beyond resentment at the depravity of the offender. Therefore, those animals that were not used for food or milk were not perceived as being defiled or "humanized."

The anxiety over observing strict boundaries between species constitutes the most plausible explanation as to why sex with animals was harshly prosecuted. Following the logic of medieval scholastics, it is not only people that should copulate with other people, animals should also copulate with one of their own kind. Basically, cross-breeding was considered to be threatening to the fragile natural order and was deemed to be extremely upsetting. ${ }^{8}$ To alleviate these fears, Russian courts focused on the materiality of the act: by accepting explanations of the absence of any malicious intent from the perpetrators and punishing their body and soul, the courts send a message to local communities that they were guarding the boundaries of humanity. The strategies they employed, though, aimed at restoring a community's peace by ruling that these incidents were isolated and infrequent acts of "filth" due to a mental deficiency caused by drinking or young/old age. The perpetrators were temporarily removed to monasteries to serve penances and the cows were killed to give local communities time to settle. These strategies also reinforced the idea that cross-species copulation was not a consciously-made choice, which thereby excluded any speculation about desire, sexual experimentation and tolerance to sex with animals.

\footnotetext{
${ }^{84}$ Fudge, "Monstrous Acts: Bestiality in Early Modern England," 25.
} 